\title{
Comparison of the Energy Absorption of Closed Cell Aluminum Foam Produced by Various Foaming Agents
}

\author{
N. Movahedi ${ }^{\mathrm{a}, 1}$ and S. M. H. Mirbagheri ${ }^{\mathrm{b}}$ \\ ${ }^{a}$ Department of Materials and Industrial Engineering, Semnan University, Semnan, Iran \\ b Department of Mining and Metallurgical Engineering, Amirkabir University of Technology, \\ Tehran, Iran \\ ${ }^{1}$ Nima.movahedi@gmail.com
}

УДК 539.4

\section{Сравнительный анализ энергопоглощения пористых структур с закрытыми ячейками на основе алюминиевого сплава с различными пенообразующими добавками}

\author{
Н. Мовахеди ${ }^{\text {, }}$ С. М. Х. Мирбагхери \\ а Университет г. Семнан, Иран \\ ${ }^{6}$ Технологический университет им. Амира Кабира, Тегеран, Иран
}

Исследовано влияние пенообразующих добавок гидрида титана $\mathrm{TiH}_{2}$ и карбоната кальиия $\mathrm{CaCO}_{3}$ на энергопоглощение в пористых структурах с закрытыми ячейками на основе алюминиевого сплава А356. Образиы с двумя различными пористыли структурами были получены путем добавки $\mathrm{TiH}_{2}$ и $\mathrm{CaCO}_{3}$ в расплав алюминиевого сплава А356 при температуре $700^{\circ} \mathrm{C}$. Электронно-микроскопический анализ образиов показывает, что ячейки структур, полученных путем добавки $\mathrm{CaCO}_{3}$, являются более мелкими и однородными, чем в случае добавки $\mathrm{TiH}_{2}$. Механические характеристики пористых образиов определяли по данным испытания на одноосное сжатие. Установлено, что при 50\%-ном уровне деформации энергопоглощение образиов, полученных путем добавки $\mathrm{CaCO}_{3}$, на 100\% выше такового образиов, полученных при добавке $\mathrm{TiH}_{2}$.

Ключевые слова: пористая структура с закрытыми ячейками на основе алюминиевого сплава, пенообразующая добавка, ячеистая структура, энергопоглощение.

Introduction. Aluminum foam (AF) is one of the most important types of cellular metals that can be produced with an open or closed cell structure. This material has a broad range of applications in a variety of industries such as transportation, building, aerospace, and automotive. Aluminum foams can be produced with powder metallurgy or melting techniques. On an industrial scale, the most promising method for the production of aluminum foam is melting. According to the bubble formation mechanism, there are two methods for the production of closed-cell aluminum foams through melting: air injection [1] or incorporation of foaming agent [2] in powder form to the aluminum melt. In both methods, the aluminum melt would first be thickened by appropriate additives such as $\mathrm{SiC}_{\mathrm{p}}$ [3], $\mathrm{Al}_{2} \mathrm{O}_{3}$ [4] particles, or calcium granules [5]. Then, the foaming process would be completed by the injection of air or the addition of an appropriate foaming agent. Titanium hydride $\left(\mathrm{TiH}_{2}\right)$ is the material most frequently used as a foaming agent in the aluminum foam production industry. But there are some important considerations that should be taken into account during the fabrication of aluminum foam with $\mathrm{TiH}_{2}$ in order to avoid deterioration of the mechanical properties of the resultant foam. For example, Matijasevic 
and Banhart showed that heat pre-treatment of the $\mathrm{TiH}_{2}$ powder is necessary to improve cell size distribution [6]. The price of this material is also a controversial topic which exists among producers of aluminum foam on an industrial scale. And, one of the important factors that influence the final price of closed-cell aluminum foam in the market is related to $\mathrm{TiH}_{2}$ cost. Other foaming agents, such as $\mathrm{CaCO}_{3}$, have also been applied successfully to produce closed cell aluminum foams [7]. In this research, two distinct closed cell aluminum foams produced with $\mathrm{TiH}_{2}$ and $\mathrm{CaCO}_{3}$ as foaming agents at the same foaming temperature with a casting method. In spite of studies done separately producing closed cell aluminum foams with these foaming materials, a comparative study to analyze the cellular structures and mechanical properties of relevant foams has not been done carefully. The main objective of this study is to evaluate and compare the mechanical properties and cellular structure of these foams. This study will help to determine which of these two foaming agents is more suitable for the synthesis of closed cell aluminum foam for applications such as energy absorption. In fact, in this study no foaming agent has been rejected, but which one is more appropriate for particular applications was shown.

1. Materials and Experimental Methods. The aluminum foams in this study were synthesized by melting. For this purpose, two distinct closed-cell A356 alloy structures were prepared by adding $\mathrm{TiH}_{2}$ and $\mathrm{CaCO}_{3}$ as foaming agents at the same foaming temperature. The foaming process is comprised of four stages when $\mathrm{TiH}_{2}$ is used as the gas releasing agent: (i) melting aluminum alloy at $700^{\circ} \mathrm{C}$; (ii) the addition of $2 \mathrm{wt} . \%$ calcium metal $(1-3 \mathrm{~mm})$ and stirring the molten aluminum at 500-700 rpm for $10 \mathrm{~min}$ to make the molten metal viscous enough; (iii) the addition of $1 \mathrm{wt} \% \%$ heat treated $\mathrm{TiH}_{2}$ to the $\mathrm{Al}-\mathrm{Ca}$ composite at 1200-1500 rpm for $1 \mathrm{~min}$; (iv) pouring the precursor to the mold and holding it for $3 \mathrm{~min}$ at $700^{\circ} \mathrm{C}$ to produce closed aluminum foam. For the aluminum foam structure that was made with calcium carbonate, the foaming procedure involved three stages: (i) melting A356 aluminum alloy at $700^{\circ} \mathrm{C}$; (ii) incorporation of $5 \mathrm{wt} . \% \mathrm{CaCO}_{3}$ into the melt and stirring for $1 \mathrm{~min}$ at $1200-1500 \mathrm{rpm}$; (iii) holding the precursor at $700^{\circ} \mathrm{C}$ for $5 \mathrm{~min}$. In the latter sample, it was shown that the calcium oxide produced as a result of $\mathrm{CaCO}_{3}$ decomposition will thicken the molten aluminum, therefore no other ingredient was added before the foaming stage. The calcium oxide makes the molten aluminum viscous enough to entrap the produced $\mathrm{CO}_{2}$ bubbles inside the liquid phase. Uniaxial compressive tests according to ASTM E9 were performed on aluminum foam rectangular specimens with a dimension of $25 \times 25 \times 20 \mathrm{~mm}$ to evaluate the mechanical properties and energy absorption of the cellular structures. A scanning electron microscope was also utilized to observe the pore structure and morphology of the aluminum foams.

2. Results and Discussions. Figure 1 reveals the compressive stress-strain curves of the foam samples under a uniaxial compression test. In both cases, the curves exhibit three distinct regions. The first stage is the initial deformation zone where stress increases linear to the peak. After that, the curve continues into the stress plateau region $\sigma_{p l}$, which represents cell collapse. In this stage, cells will collapse and strain is not recoverable. This behavior is important for cellular materials when their main application is energy absorption. In the third stage, densification of the foam will occur. In Fig. 2, the relative density $\left(\rho_{r}\right)$ and porosity $(\phi)$ of the synthesized cellular structures in this study is shown. The relative density and porosity of the aluminum foams are calculated in Eqs. (1) and (2), respectively, [8]. The density of the foam samples was determined according to the ASTM D6683 standard for each sample

$$
\begin{gathered}
\rho_{r}=\frac{\rho_{f}}{\rho_{s}}, \\
\phi=1-\frac{\rho_{f}}{\rho_{s}} .
\end{gathered}
$$




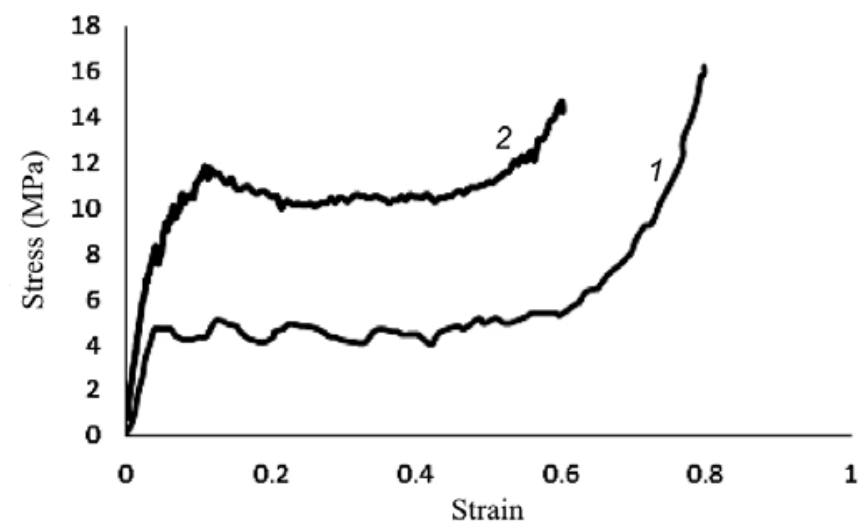

Fig. 1. Compressive stress-strain curves of $\mathrm{AF}_{\mathrm{CaCO}_{3}}$ (1) and $\mathrm{AF}_{\mathrm{TiH}_{2}}$ (2) samples.

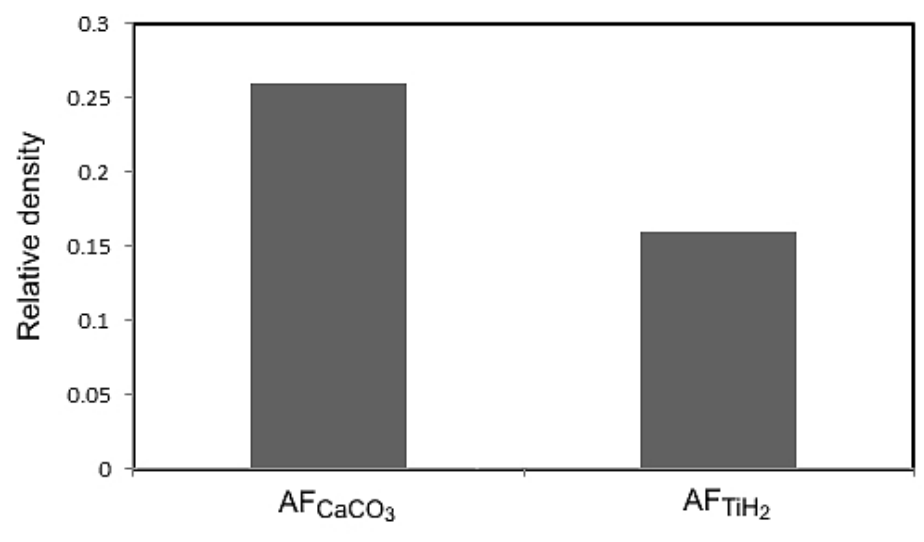

a

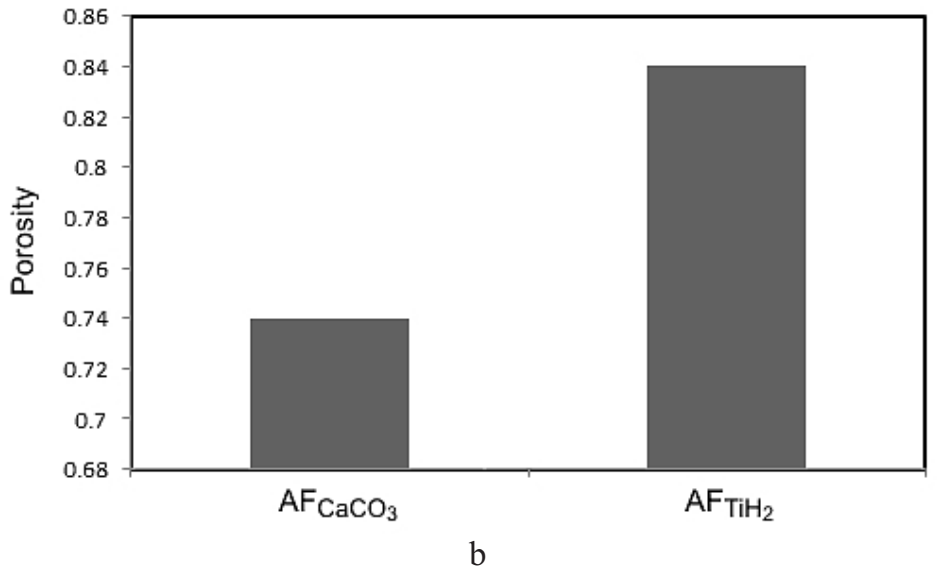

Fig. 2. Relative density (a) and porosity of aluminum foam samples (b).

The relative density of $\mathrm{AF}_{\mathrm{CaCO}_{3}}$ is about $18 \%$ higher than that of $\mathrm{AF}_{\mathrm{TiH}_{2}}$. It can be seen that the relative density of the foam affects the compressive stress-strain curves. The plateau region in the aluminum foam sample with $\mathrm{CO}_{2}$ applied to produce the pores is shorter in comparison with the $\mathrm{AF}_{\mathrm{TiH}_{2}}$ sample, or, in other words, under compressive loads, 
the use of $\mathrm{TiH}_{2}$ as a foaming agent produces a cellular structure with a higher porosity level that density the cellular structure at higher strains, meaning that this structure allows the bubbles to collapse and deform. This behavior is also reported for aluminum foams that are produced using a powder metallurgy method [4]. Also, the relative density of the aluminum foam has an important effect on the mechanical properties of the cellular structure. From the compressive stress-strain curves, it can be deduced that the closed cell structures in $\mathrm{AF}_{\mathrm{CaCO}_{3}}$ show greater compressive strength in comparison to the $\mathrm{AF}_{\mathrm{TiH}_{2}}$ sample (Fig. 3).

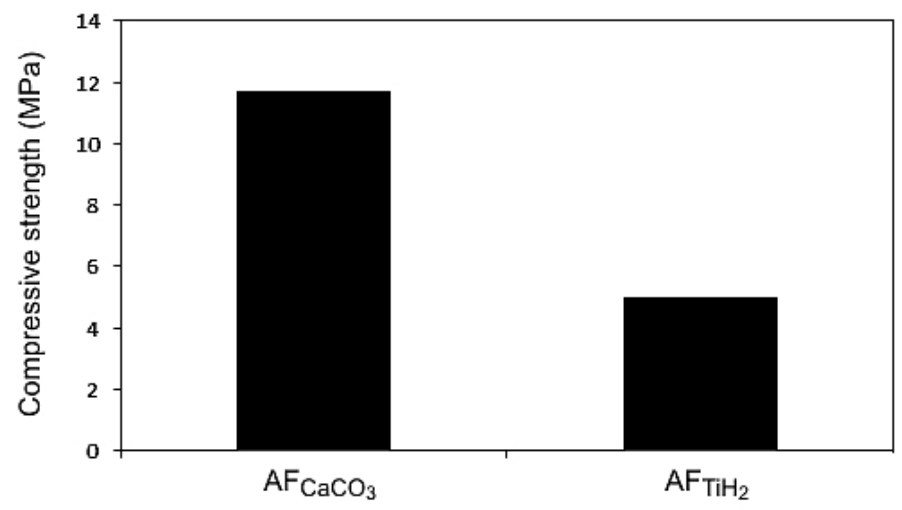

Fig. 3. Compressive strength of aluminum foam samples.

Under compressive loads, according to the Gibson-Ashby model, a linear relationship exists between relative yield stress and relative density [8]. Unlike open cell foams, the stretching of the cell faces also occurs, as well as cell edge bending. Therefore, the structure of the foam in this case would be important. The microstructure of the aluminum foams is illustrated in Fig. 4.

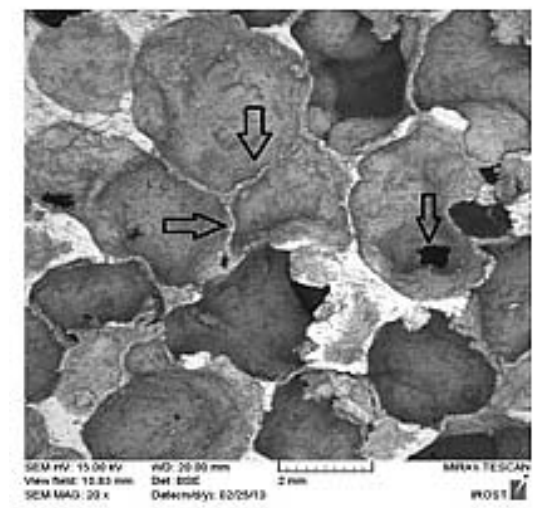

a

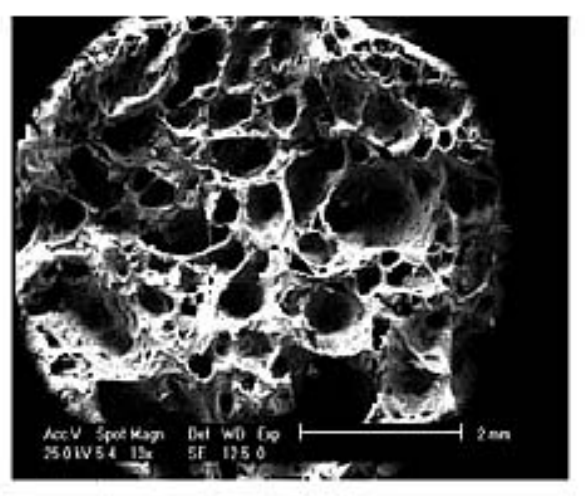

b

Fig. 4. Microstructure of aluminum foam samples produced with different foaming agent $\mathrm{TiH}_{2}$ (a) and $\mathrm{CaCO}_{3}$ (b).

It is obvious that the pore size of the closed cell aluminum foams produced with $\mathrm{CaCO}_{3}$ is considerably smaller than those synthesized with $\mathrm{TiH}_{2}$. The polygonal shape of the pores in the cellular structure reveals that the interaction of the bubbles within the molten aluminum that has been foamed with $\mathrm{TiH}_{2}$ is greater than with $\mathrm{CO}_{2}$ gases.

In Fig. 5, the interaction of two adjacent growing bubbles and the development of the transient cell wall is shown. As a result of rapid bubble expansion, transient cell walls 
develop between the two pores and will produce a cellular structure with non-rounded bubbles and move the system away from equilibrium. The magnitude of the interaction between two neighboring cells depends on surface tension, viscosity, growth velocity, and the size of the bubbles [9]. As the foaming agent is added to the molten aluminum at a specific temperature, decomposition will occur, and the gas released will interact with the molten aluminum. According to the macroscopic images of the cellular structures in Fig. 6, it is obvious that in the aluminum foam sample with $\mathrm{TiH}_{2}$ there are some signs of cell wall curvature.

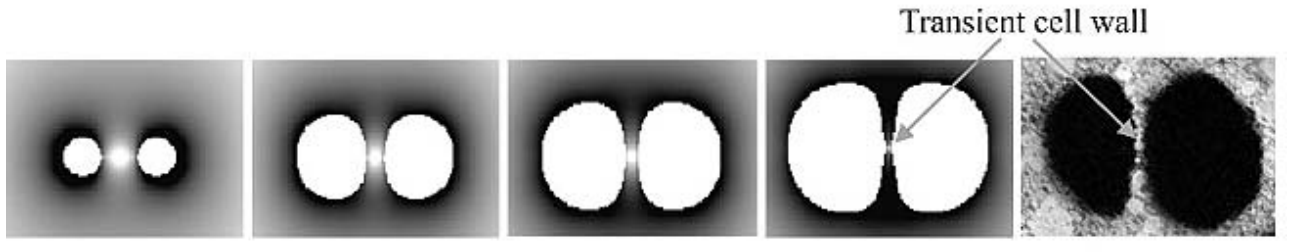

Fig. 5. Interaction of growing adjacent bubbles and development of transient cell wall [9].

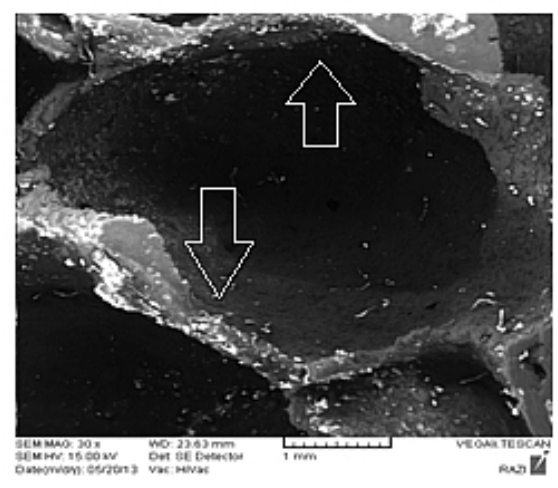

a

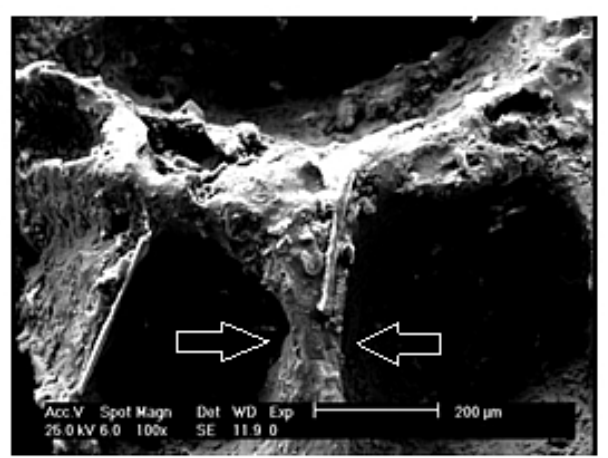

b

Fig. 6. Pore morphology and cell wall of produced aluminum foam sample with $\mathrm{TiH}_{2}$ (a) and $\mathrm{CaCO}_{3}$ (b).

Under compressive deformation, these polygonal shaped cells will behave as stress concentration centers and deteriorate the mechanical properties of the cellular structures. While in the aluminum foam sample with $\mathrm{CaCO}_{3}$, the microscopic structure reveals a more uniform cell shape. So, under compressive loads, the cellular structure resists plastic hinges and more stress is required to collapse the structure. The compressive stress-strain curve of $\mathrm{AF}_{\mathrm{CaCO}_{3}}$ shows the sample hardening in the first stage of deformation. This phenomenon contributes to the thicker cell walls of this sample, while the thinning, rupture, and curvature of the cell walls and cell faces in the aluminum foam sample with $\mathrm{TiH}_{2}$ foaming agent deteriorates the yield strength of the cellular structure considerably. (Cell wall and cell edge ruptures and curvatures are indicated in Fig. 4a and Fig. 6a.) Another parameter that may increase the strength of the aluminum foam sample produced with $\mathrm{CaCO}_{3}$ is the intrinsic property of $\mathrm{CaO}$ in improving cell wall stability and strength in comparison to calcium. Energy absorption is an important factor in evaluating the properties of metal foams, and the energy absorption of the aluminum foams was calculated according to Eq. (3) [8]:

$$
W=\int_{0}^{\varepsilon_{D}} \sigma d \varepsilon
$$


where $W$ is the absorbed energy, $\sigma$ is the compressive stress, and $\varepsilon_{D}$ is the densification strain.

In Fig. 7, the energy absorption of the aluminum foam samples is shown. The strain at which densification takes place is known as the densification strain $\left(\varepsilon_{D}\right)$ and is calculated by Eq. (4):

$$
\varepsilon_{D}=\alpha\left[1-1.4\left(\frac{\rho_{f}}{\rho_{s}}\right)+0.4\left(\frac{\rho_{f}}{\rho_{s}}\right)^{3}\right],
$$

where $\alpha$ is a constant, approx. 1 for cellular structure, and $\rho_{f}$ and $\rho_{s}$ are the foam and cell wall material density [9].

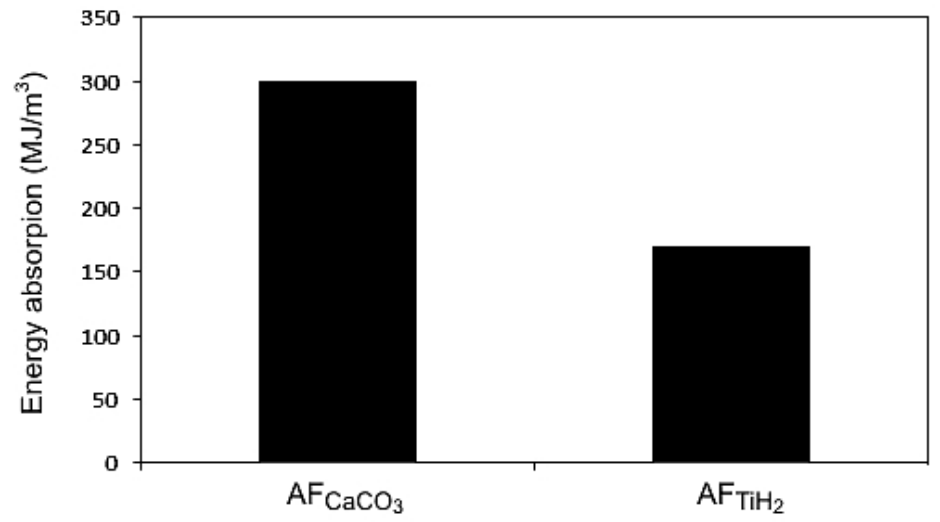

Fig. 7. Energy absorption of aluminum foams.

As seen in Fig. 1, the densification strain of $\mathrm{AF}_{\mathrm{CaCO}_{3}}$ is about 0.48 , and for $\mathrm{AF}_{\mathrm{TiH}_{2}}$ is about 0.77. This means that in $\mathrm{AF}_{\mathrm{TiH}_{2}}$, densification will occur at higher strain levels, and consequently the surface area under the compressive stress-strain curve will increase. However, up to $50 \%$ strain, the energy absorption of $\mathrm{AF}_{\mathrm{CaCO}_{3}}$ is considerably higher.

Conclusions. In this work, two distinct closed cell aluminum foams were fabricated via melting at identical foaming temperature. Mechanical investigations revealed that due to the thicker cell walls and finer pores within $\mathrm{AF}_{\mathrm{CaCO}_{3}}$, the energy absorption was considerably higher than that of $\mathrm{AF}_{\mathrm{TiH}_{2}}$. This characteristic makes $\mathrm{AF}_{\mathrm{CaCO}_{3}}$ more suitable for certain applications, particularly in the automotive industry. It is also important to take into account that the processing and fabrication of closed cell aluminum foam with calcium carbonate is cheaper and easier to handle in comparison to the $\mathrm{TiH}_{2}$ foaming agent.

\section{Р езюм е}

Досліджено вплив пінотвірних додатків гідриду титана $\mathrm{TiH}_{2}$ i карбонату кальцію $\mathrm{CaCO}_{3}$ на енергопоглинання у пористих структурах із закритими комірками на основі алюмінієвого сплаву. Зразки 3 двома різними пористими структурами отримано шляхом додатка $\mathrm{TiH}_{2}$ i $\mathrm{CaCO}_{3}$ у розплав алюмінієвого сплаву $\mathrm{A} 356$ за температури $700^{\circ} \mathrm{C}$. Електронно-мікроскопічний аналіз зразків показав, що комірки структур, отриманих шляхом додатка $\mathrm{CaCO}_{3}$, є більш мілкими й однорідними, ніж у випадку додатка $\mathrm{TiH}_{2}$. Механічні характеристики пористих зразків визначали за даними 
випробувань на одновісний стиск. Установлено, що за 50\%-ного рівня деформації енергопоглинання зразків, що отримані шляхом додатка $\mathrm{CaCO}_{3}$, на $100 \%$ більше, ніж зразків, отриманих при додатку $\mathrm{TiH}_{2}$.

1. D. Wang, W. Xue, and Z. Shi, "Cell size prediction of a closed aluminum foam," Mater. Sci. Eng. A, 431, No. 1-2, 298-305 (2006).

2. L. E. G. Cambronero, J. M. Ruiz-Roman, F. A. Corpas, and J. M. Ruiz Prieto, "Manufacturing of Al-Mg-Si alloy foam using calcium carbonate as foaming agent," J. Mater. Process. Technol., 209, No. 4, 1803-1809 (2009).

3. O. Prakash, H. Sang, and J. D. Embury, "Structure and properties of Al-SiC foam," Mater. Sci. Eng. A, 199, No. 2, 195-203 (1995).

4. M. Alizadeh and M. Mirzaei-Aliabadi, "Compressive properties and energy absorption behavior of $\mathrm{Al}-\mathrm{Al}_{2} \mathrm{O}_{3}$ composite foam synthesized by space-holder technique," Mater. Des., 35, 419-424 (2012).

5. N. Movahedi, S. M. H. Mirbagheri, and S. R. Hosseini, "Effect of foaming temperature on the mechanical properties of produced closed-cell A356 aluminum foams with melting method," Met. Mater. Int., 20, No. 4, 757-763 (2014).

6. B. Matijasevic and J. Banhart, "Improvement of aluminium foam technology by tailoring of blowing agent," Scripta Mater., 54, 503-508 (2006).

7. J. Lázaro, E. Solórzano, and M. A. Rodriguez-Pérez, "Alternative carbonates to produce aluminium foams via melt route," Proc. Mater. Sci., 4, 275-280 (2014).

8. H. P. Degischer and B. Kriszt, Handbook of Cellular Metals Production, Processing, Applications, Wiley-VCH Verlag GmbH, Weinheim (2002).

9. C. Koerner, Integral Foam Molding of Light Metals, Springer-Verlag, BerlinHeidelberg (2008).

Received 27. 04. 2015 